\title{
Yoko Ono's Magical Thinking
}

\section{Vera Mackie, University of Wollongong}

\author{
Guernica
}

Nanking

Dresden

Hiroshima

My Lai

In Yoko Ono's recent artwork, Mended Cups, a series of dates and place names are painted on saucers in Ono's handwriting, matched with coffee cups decorated with a pattern of mended cracks (Ono 2014).

Each of these place names - Guernica, Nanking, ${ }^{1}$ Dresden, Hiroshima and My Lai - is associated with a violent event in the course of the twentieth century, and all occurred in the span of Ono's lifetime (she was born in 1933).

On 26 April 1937 German and Italian planes bombed the northern Spanish city of Guernica in support of Franco's nationalist government (Steer 1937).

On 13 December 1937 Japanese troops killed, tortured and raped hundreds of thousands of residents of the Chinese city of Nanking (Fogel 2000).

\footnotetext{
${ }^{1}$ Although the spelling 'Nanjing' is often used nowadays, I will follow Ono in using the older spelling 'Nanking.'

PORTAL Journal of Multidisciplinary International Studies, vol. 13, no. 1, January 2016.

Cultural Works: Practices of Inscription and Remembrance.

(C) 2016 [Vera Mackie]. http://dx.doi.org/10.5130/portal.v13i1.4779.

This is an Open Access article distributed under the terms of the Creative Commons Attribution 4.0 Unported (CC BY 4.0) License (https://creativecommons.org/licenses/by/4.0/), allowing third parties to copy and redistribute the material in any medium or format and to remix, transform, and build upon the material for any purpose, even commercially, provided the original work is properly cited and states its license. 
On 13 February 1945 Allied troops bombed the German city of Dresden, destroying an important cultural centre associated with fine porcelain, and killing over twenty thousand people (Gregg 2015).

On 6 August 1945 the US army dropped an atomic bomb that flattened the Japanese city of Hiroshima, killing over a hundred thousand, and causing countless more to suffer radiation sickness, to develop cancers, or to pass on genetic mutations to their children (Hersey 1946).

On 16 March 1968 US troops massacred hundreds of inhabitants of the village of My Lai in Vietnam (Hersh 2015).

The perpetrators of these atrocities were from all sides: Germans, Italians, Americans, the Japanese. It might have been expected that the Holocaust would be a major reference point here. Perhaps, though, Guernica, Nanking, Dresden, Hiroshima and My Lai were chosen by Ono because they signify events that can be pinned down to a particular time and place. It is thus possible to tie the memorialisation of each of these events to a specific date. ${ }^{2}$

The sixth cup and saucer bear the name of New York City. This is not, however, a reference to the terrorist attacks on the World Trade Centre on 11 September 2001, as might be expected. Rather, the date is 8 December 1980, the day Ono's partner John Lennon (1940-1980) was shot dead by Mark Chapman outside the Dakota Building.

\section{How can you mend a broken heart? $?^{3}$}

At first it seems as if time has stopped on 8 December 1980, with the sixth cup and saucer referring to the day, thirty-five years ago, when John Lennon was shot. This reflects the experience of trauma or bereavement, where the individual is often unable to move beyond the traumatic event (Greenspan et al. 2014: 199; 216-17).

Stop all the clocks, cut off the telephone. ${ }^{4}$

\footnotetext{
${ }^{2}$ In fact, many of the events were spread over a few days, but it seems to me that Ono has chosen events that can be memorialised on a particular day, unlike the extended time period of the Holocaust.

3 Gibb and Gibb (1971).

4 Auden (1940: 91).
} 


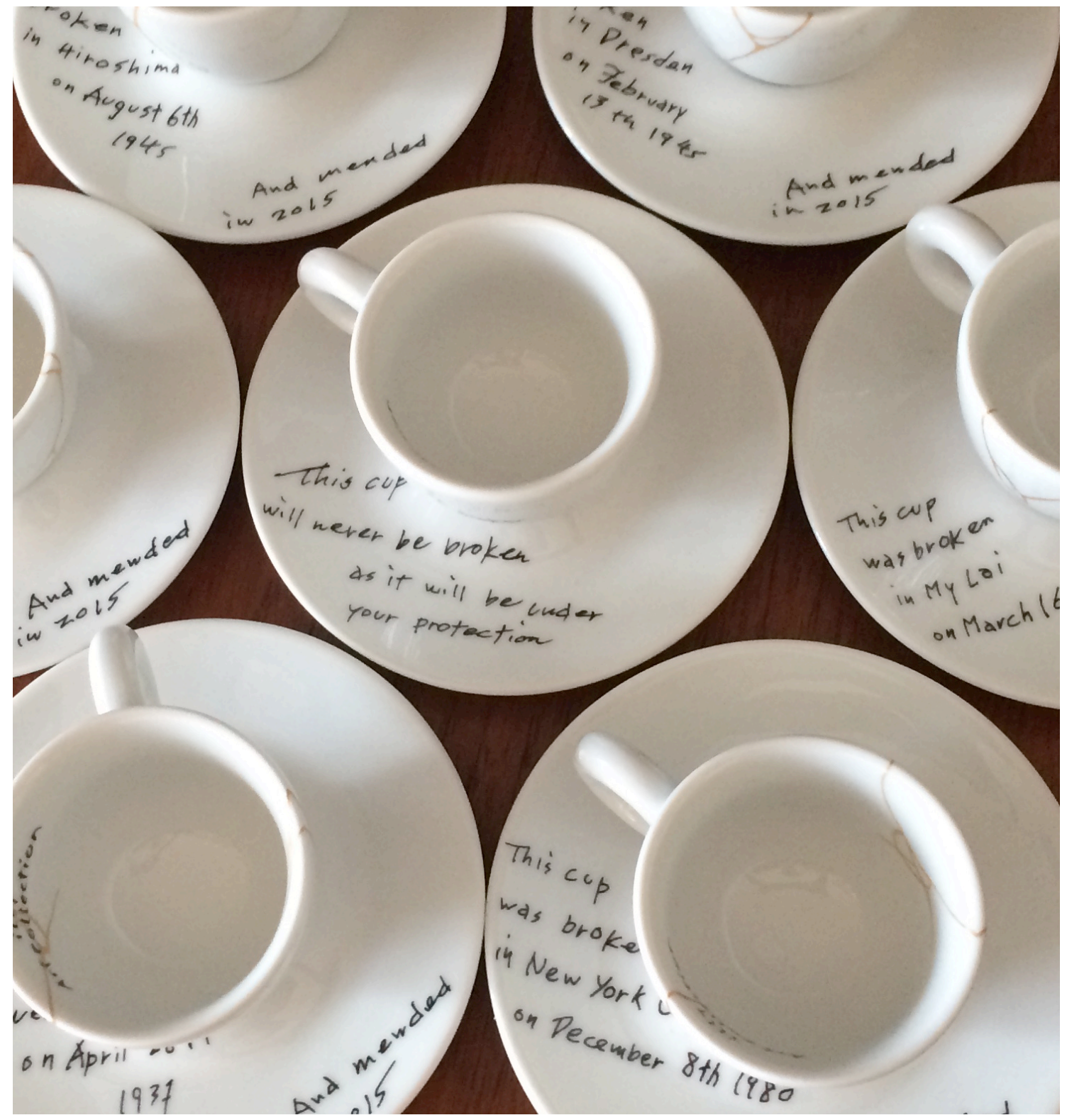

Figure 1: Yoko Ono's Mended Cups (C) Vera Mackie

Nevertheless, there is a message of hope in Ono's work. For each of the cups has been 'mended,' according to the words on the saucers.

This cup was broken in Guernica on April 26th 1937

And mended in 2015

This cup was broken in Nanking on December 13th 1937

And mended in 2015

This cup was broken in Dresden on February 13th 1945

And mended in 2015 
This cup was broken in Hiroshima on August 6th 1945

And mended in 2015

This cup was broken in My Lai on March 16th 1968

And mended in 2015

This cup was broken in New York City on December 8th 1980

And mended in 2015

Broken crockery is a common side effect of traumatic events. ${ }^{5}$ The idea that the cups destroyed in such catastrophes could be mended, that the events could be undone, is an example of magical thinking - the idea that one's thoughts can influence what happens in the world. This is the mechanism of prayers, blessings, incantations, spells.

Touch wood.

Fingers crossed.

Cross my heart.

Don't step on the cracks.

Like Ono, Joan Didion has explored grief and mourning, but through writing rather than conceptual art. In her memoir, The Year of Magical Thinking, Didion describes her state of mind in the first year after the death of her partner John Dunne (1932-2003). ${ }^{6}$ While dealing with the practicalities of her partner's death, her days and nights are filled with irrational, magical thoughts, as if she could undo the events of the evening of 30 December 2003, when Dunne died of a massive heart attack. 'I was thinking as small children think, as if my thoughts or wishes had the power to reverse the narrative, change the outcome' (Didion 2006 [2005]: 35).

Magical thinking takes the form of refusing to throw out her husband's shoes, for he would surely need them if he were to return (Didion 2006 [2005]).

I wake and feel the fell of dark not day. ${ }^{7}$

\footnotetext{
${ }^{5}$ See the everyday objects collected in the Hiroshima Peace Museum and the discussion in Kilpatrick (2015); see also Cole (2015).

${ }^{6}$ The Year of Magical Thinking was originally published in 2005, but page numbers below refer to the Harper Perennial Edition of 2006.

${ }^{7}$ Hopkins (1985 [1918]; cited in Didion 2006: 32).
} 
Mended Cups, too, can be understood as an attempt to come to terms with grief and mourning. It also, however, draws on earlier art works by Ono.

\section{WISH PIECE 2}

Mend an object.

When you go through the process of mending,

You mend something inside your soul as well. Think of a 'crack' in your own life or the world.

Ask for it to be healed as you mend the object. (Kent 2014: 8)

This work can be thought of as a new iteration of Ono's instruction pieces, where she invites the reader to engage in a thought experiment (Mackie 2012). The cups, however, are different, in that they are physical objects rather than purely conceptual art.

Even so, Mended Cups does invite various acts of imagination.

The cups are not really broken. Rather the cracks are painted on with gold-coloured paint. It thus takes an act of imagination to see each broken cup and to see it mended.

The golden paint on the cups refers to an early modern Japanese technique called kintsugi, or kintsuguroi, which could be translated as 'mending with gold.' According to this technique, a broken tea bowl was mended with lacquer and sprinkled with powdered gold. The bowl could then be used again, and the mended faults would become part of the beauty of the object. ${ }^{8}$

Mended Cups is a collaboration between Ono, the Museum of Modern Art and the Illy coffee company, which has also collaborated with such artists as David Byrne, Jeff Koons, Robert Rauschenberg and Marina Abramovich. Most people who purchase the cups will probably never use them, simply treating them as a 'collectible.' Imagine, however, what it would be like to use the cups every day, to be reminded that something terrible had happened on, say, 8 December 1980.

To link mourning with a daily act like drinking a cup of coffee captures the quotidian reality of grief. This everydayness is also captured by Didion:

\footnotetext{
${ }^{8}$ For an example of kintsugi and an explanation, see Kaplan (undated).
} 
One night I found myself taking from the cupboard not one of the plates I normally used but a crackled and worn Spode plate, from a set mostly broken or chipped, in a pattern no longer made, "Wickerdale." This had been a set of dishes, cream with a garland of small rose and blue flowers and ecru leaves, that John's mother had given him for the apartment he rented on East Seventythird Street before we were married. John's mother was dead. John was dead. And I still had, of the "Wickerdale" Spode, four dinner plates, five salad plates, three butter plates, a single coffee cup, and nine saucers. I came to prefer these dishes to all others. (2006: 163)

To drink from one of Ono's mended cups would transform the morning cup of coffee into a ritual of mourning.

Indeed, in some cultures, communication with the deceased is just such an everyday ritual. In Japan, for example, photographs of ancestors are displayed on a shelf, often near a kitchen or hearth. Family members greet or pray to the lost relatives at least once a day, and present them with fruit, a bowl of rice, water, or even a cup of sake on special occasions.

And all through my coffee break time, I say a little prayer for you. ${ }^{9}$

Ono's Mended Cups, in its everydayness, is much closer to popular culture than high art. This quotidian sensibility is shared with pop music, where everyday sights - coffee cups, red doors, girls in summer dresses — are refracted through the prism of loss.

I see a red door and I want it painted black ... I see the girls walk by dressed in their summer clothes

I have to turn my head until my darkness goes. ${ }^{10}$

It is perhaps appropriate that this pop sensibility is linked to mourning for the popular music icon John Lennon.

Some might find it difficult, or even offensive, to make the leap from individual acts of mourning to the mass atrocities of Guernica, Nanking, Dresden, Hiroshima and My Lai. It could also be argued, however, that the only way to comprehend such atrocities is to break them down into countless individual acts of mourning, countless daily rituals of prayer, wishful thinking and magical thinking.

\footnotetext{
${ }_{9}^{9}$ Bacharach and David (1967).

${ }^{10}$ Richards and Jagger (1966).
} 
Didion's memoir ends on December 2004, the first anniversary of her husband's death. While grief is often associated with a continuous present, anniversaries are also important, particularly as years go by. The impulse to mark anniversaries is captured in the dates memorialised on the mended cups.

In addition to the set of six mended cups and saucers there is one more- the 'Unbroken Cup.' There are no cracks on this cup and the saucer bears the following words:

This cup will never be broken as it will be under your protection.

This is just one more element of magical thinking. If only we could prevent accidents and catastrophes just by exercising enough attention and concentration. Nevertheless, this final piece of the artwork takes the narrative beyond the past of tragedy and the present of mourning, to give a sense of futurity.

\section{Reference List}

Auden, W. H. 1940, Another Time. Faber and Faber, London.

Bacharach, B. \& David, H. 1967, 'I Say a Little Prayer for You.' BMG Gold Songs, New Hidden Valley Music Co., Casa David Music, Universal Music Corporation.

Cole, T. 2015. 'Object Lesson,' New York Times (22 March). Online, available: http://www.nytimes.com/2015/03/22/magazine/object-lesson.html? r=1 [accessed 4 January 2016].

Didion, J. 2006, The Year of Magical Thinking. Harper Collins, London [originally Knopf, New York, 2005].

Fogel, J. A. (ed.) 2000, The Nanjing Massacre in History and Historiography. University of California Press, Berkeley. doi: http://dx.doi.org/10.1525/california/9780520220065.001.0001.

Gibb, B. \& Gibb, R. 1971. 'How Can You Mend a Broken Heart?,' Warner/Chappell Music, Inc., Universal Music Publishing Group.

Greenspan, H., Horowitz, S. R. Kovacs, E., Lang, B., Laub, D., Waltzer, K. \& Wieviorka, E. 2014, 'Engaging Survivors: Assessing “Testimony” and "Trauma” as Foundational Concepts,' Dapim: Studies on the Holocaust, vol. 28, no 3: 190-226. doi: http://dx.doi.org/10.1080/23256249.2014.951909.

Gregg, V. 2015, 'Dresden Bombing 70 Years On: A Survivor Recalls the Horror He Witnessed in the German City,' The Independent. Online, available: http://www.independent.co.uk/news/world/world-history/dresden-bombing-70-years-on-asurvivor-recalls-the-horror-he-witnessed-in-the-german-city-10042770.html [accessed 12 December 2015].

Hersey, J. 1946, 'Hiroshima,' The New Yorker (31 August).

Hersh, S. 2015, 'The Scene of the Crime,' The New Yorker (30 March). Online, available: http://www.newyorker.com/magazine/2015/03/30/the-scene-of-the-crime [accessed 12 December 2015].

Hopkins, G. M. 1985 [1918], 'I Wake and Feel the Fell of Dark, Not Day,' Gerard Manley Hopkins: Poems and Prose. Harmondsworth, Penguin Classics.

Kaplan, H. undated, 'Friday Fave: Tea Bowl,' Bento: Art Outside the Box. Online, available: http://bento.si.edu/from-the-collections/japanese-art/friday-fave-tea-bowl/ [accessed 22 August 2015].

Kent, R. 2014, 'Future Now,' in War Is Over! If You Want it, (ed.) R. Kent. Museum of Contemporary Art, Sydney: 8-25. 
Kilpatrick, H. 2015, 'The Recognition of Nuclear Trauma in Sagashite imasu (I am Searching),'The AsiaPacific Journal: Japan Focus, vol. 13, no, 6. Online, available: http://www.asiastudies.com/jpfocus2.html [accessed 12 December 2015].

Mackie, V. 2012, 'Instructing, Constructing, Deconstructing: The Embodied and Disembodied Performances of Yoko Ono,' in Rethinking Japanese Modernism, (ed.) R. Starrs. Global Oriental, Leiden: 490-501.

Ono, Y. 2015, 'Yoko Ono Mended Cups and Unbroken Cup-A New Illy Art Collection \& Metaphor for Life,' Imagine Peace (14 May). Online, available: http://imaginepeace.com/archives/21306 [accessed 12 December 2015].

Richards, K. \& Jagger, M. 1966, 'Paint it Black,' Decca.

Steer, G. 1937, The Times (28 April). 